DOI: 10.15290/bsp.2019.24.04.09

Received: 21.03.2019

Accepted: 30.04.2019

Aksana Chmyha

Brest State University named after A.S. Pushkin

ch.ok.vas@gmail.com,ch.ok.vas@mail.ru

ORCID ID: https://orcid.org/0000-0002-5793-3798

\title{
The Legal Grounds of Emergence and Termination of Mandates of Members of Parliaments in Belarus and Poland: a Comparative Analysis
}

\begin{abstract}
The existing grounds for granting and terminating Belarusian and Polish parliamentary mandates from the legal point of view are nowadays rather debatable. The article presents a comparative study of these legal categories based on the considerable historical, regional and legal similarity of the above neighbouring countries and their legal doctrines. The main conclusion of this article is that a large number of similar legislative provisions is related to their essence and is preconditioned mainly by the common origin of Polish and Belarusian parliamentary institutions. Their main point is that the grounds for granting and terminating parliamentary mandates, as an integral element of their legal status, sets the time frame for exercising the authority of both Polish and Belarusian members of parliament. The existing differences between the above legal categories manifest themselves, first and foremost, in their formal expression - the implementation procedure.
\end{abstract}

Keywords: the grounds for granting mandates of parliamentarians, the grounds for terminating mandates of parliamentarians, Parliament, Belarus, Poland

\section{Introduction}

The existing grounds for granting and terminating Belarusian and Polish parliamentary mandates from the legal point of view are nowadays rather debatable, especially in Polish and Belarusian legal science. ${ }^{1}$ The grounds for granting and ter-

1 K. Grajewski, Status prawny posła i senatora, Warszawa, 2006; P. Sarnecki (ed.), Prawo konstytucyjne Rzeczypospolitej Polskiej, Warszawa 2011; L. Garlicki Prawo polskie konstytucyjne, zarys wykładu, Warszawa 2011; W. Skrzydło (ed.), Polskie prawo konstytucyjne, Lublin 2008; G.A. Va- 
minating mandates of the Sejm's deputies and National Assembly senators of the Republic of Poland, as well as those of the deputies to the House of Representatives and members of the Council of the Republic which make up the National Assembly of the Republic of Belarus, present a notable element that defines the legal standing of Belarusian and Polish members of parliament (MPs). Taking into account a certain disputability of these legal elements in the MPs' status structures from the perspective of modern legal science, as well as the considerable historical, regional and legal similarity of the two neighbouring countries, let us perform a more detailed comparative study of these categories.

\section{Direct Election as an Emergence of Mandate}

Thus, the only rationale and legal circumstance for granting a mandate to a deputy of the House of Representatives is direct election. The legal circumstance for granting parliamentary mandates to the members of the Council of the Republic is indirect election as well as appointment by the President of Belarus.

Note that the constitutionally set number of mandates granted to the Lower Chamber of the Belarusian Parliament - the House of Representatives - is 110. The Council of the Republic as the Upper Chamber represents the nation territorially. All in all there are 64 mandates for the Upper Chamber with each region and the city of Minsk electing eight members of the Council of the Republic by secret ballot at local base-level council sessions. A further eight members of the Council are appointed by the President of the Republic of Belarus. The total number of parliamentary mandates set by the Constitution of the Republic of Belarus equals 174 .

Legislative power in the Republic of Poland belongs to the Sejm and the Senate.

The Sejm is the Lower Chamber of the Parliament and consists of 460 deputies, also granted their mandates by election. Elections to the Polish Sejm are universal, equal, direct, proportional and conducted by secret ballot.

The Senate - the Upper Chamber - consists of 100 senators. Polish senators are granted their mandates in universal direct elections by secret ballot. Thus, the total number of Polish parliamentary mandates equals 560.

Both direct and indirect elections in the Republic of Belarus are based on the principles of universality, equality, freedom and secret ballot, which demonstrates the degree democracy and rule of law in the country. A good example in this regard is the statement made by a Belarusian professor, G.A. Vasilevich, who justly noted that only

silevich, The constitution and problems of improvement of an electoral law in the Republic of Belarus, "Journal of Russian Law" 1999, no. 5/6, p. 149-157; L.A. Nudnenko, Constitutional legal status of the deputy of the legislature governmental body in the Russian Federation, Sankt Petersburg 2004 and other literature. 
"free and fair elections give us the right to say that the people's will as that of the only source of authority is identical to the election results".

We should also emphasise the fact that the four-year term of office served by Belarusian MPs starts on the first day of the newly elected Chamber session and ends on the opening day of the first session of the House of Representatives of a newly assembled Council of the Republic (except in cases otherwise provided for in Article 8 of the framework law). ${ }^{3}$ The above fact means that newly elected MPs start exercising their mandates on the day of the first session of the House of Representatives and Council of the Republic. Previously elected MPs stay in office up to the said date. In the event of war, the term of office of MPs may be prolonged.

As for Poland, pursuant to Article 98 Section 1 of the Constitution the Polish Sejm and the Senate, in keeping with the Belarusian Parliament chambers, Polish MPs are elected for a four-year term of office. According to Polish researcher, professor Pawel Sarnecky, this procedure is typical of the Polish parliamentary tradition: ${ }^{4}$ it was formed during the post-war period and has been applied since 1952 (we know that before World War II the Polish Parliament's term of office used to be 5 year). However, the assemblies of the Polish Parliament (1993-1997, 1997-2001, 20012005 and 2007-2011) have served a full four-year term of office. This circumstance, as professor Leszek Garlicki rightly states, can be explained by the fact that the tumultuous political events of the previous years presented an obstacle in observing the above period (for example, the $5^{\text {th }}$ assembly Sejm (2005-2007) was voluntarily wound up prematurely). ${ }^{5}$

Note that Article 98, Section 1, of the Fundamental Law of Poland states that the term of office of the Sejm and the Senate shall begin on the day on which the Sejm assembles for its first sitting and shall continue until the day preceding the assembly of the Sejm of the succeeding term of office. These provisions also stay in force if the Sejm's term of office is prolonged or shortened. We believe that the above constitutional regulation serves to eliminate any chance of the executive power exceeding its authority during the period when the term of office of one Sejm and Senate comes to an end, but the succeeding one has yet to begin, thus securing the operational stability and continuity of state power.

2 Vasilevich G.A., The constitution and problems of improvement of an electoral law in the Republic of Belarus, "Journal of Russian Law" 1999, no. 5/6, p. 149.

3 About the status of the deputy of the House of Representatives, member of the Council of the Republic of the National Assembly of the Republic of Belarus: Law of the Republic of Belarus, 04. 11.1998, No. 196-Z: in an edition. Law of the Republic of Belarus of 17.07.2018.

4 P. Sarnecki (ed.), Prawo..., op. cit., p. 242.

5 Ibidem, p. 200. 
In fact, "we cannot hold recognition by the representative body that elects a deputy as a precondition for the above deputy's authority ... This would contradict the very democratic core of the popular representation institution". ${ }^{6}$

It should be noted that Polish legislation provides for just one circumstance that allows prolonging the Sejm's and the Senate's term of office. Namely, pursuant to the Constitution, "during a period of introduction of extraordinary measures, as well as within the period of 90 days following its termination, the term of office of the Sejm may not be shortened, nor may a nationwide referendum, nor elections to the Sejm, Senate, organs of local government nor elections for the Presidency be held, and the term of office of such organs shall be appropriately prolonged". For this purpose, the regulation defines extraordinary measures as martial law, a state of emergency or a state of a natural disaster.

The constitutional provision of the Republic of Belarus, Article 93, sets the following procedure for the chambers of Parliament to commence work. The first session of Parliament after the elections is called by the Central Commission of the Republic of Belarus on Elections and National Referenda and is convened no later than 30 days after the elections. It should be noted that the order of recognizing the authority of "people's deputies" in the Republic of Belarus is related to a special procedure set by the Parliament chambers' regulations.

In Poland, the first sitting of the newly elected Sejm takes place when summoned by the Polish President in accordance with a set procedure. Thus, the Senior Marshal appointed by the President out of the oldest deputies, opens the first sitting of the Lower Chamber. We consider it noteworthy that before the commencement of the performance of the mandate at the first sitting of the Sejm, deputies take the following oath in the presence of the Sejm: "I do solemnly swear to perform my duties to the Nation diligently and conscientiously, to safeguard the sovereignty and interests of the State, to do all within my power for the prosperity of the Homeland and the well-being of its citizens, and to observe the Constitution and other laws of the Republic of Poland". The oath may also be taken with the additional sentence "So help me, God". The deputy's oath taking procedure and the election of the Marshal of the Sejm are held by the Senior Marshal. Deputies who missed the sitting of the Sejm as well as those who were granted their mandates during the Parliament's term of office, take the deputy's oath at the first sitting they attend. The deputies having taken their oaths, the Senior Marshal holds the Marshal of the Sejm's election. Having been elected by an absolute majority roll-call vote, the Marshal of the Sejm takes the chair.

We believe that legitimization of the regulation requiring Belarusian MPs to take an oath at the first sitting of each Chamber of the Parliament as well as to secure their performance efficiency, would logically wrap up the formal recognition of their mandates. We suppose that the oath may be taken in the presence of the Central Commis-

Bezuglov A.A., Sovetsky deputy. State and legal status, Moscow 1971, p. 23-25. 
The Legal Grounds of Emergence and Termination of Mandates of Members...

sion of the Republic of Belarus on Elections and National Referenda represented by its Chairperson.

\section{Termination of Mandate}

As for the grounds for terminating MPs' powers, we find it interesting to consider in the framework of legal theory the view of Russian researcher L.A. Nudnenko, who believes that "deputies' mandates may be terminated as a result of expiry or premature termination. A deputy's mandate expires regardless of the deputy's will or awareness"' The author states that deputies' mandates expire at the end of the state legislative body's term of office and therefore defines the following grounds for terminating their mandates: deputy's death; court decision declaring the person elected as a deputy is missing or deceased pursuant to a court resolution in force; court decision declaring the person elected as a deputy is fully or partially incapacitated. However innovative this approach might be, we do not think it necessary to isolate the term "expiry" in relation to a deputy's mandate as being unique. We believe that the loss of a deputy's mandate as a result of its expiry and premature termination should be united under a common theoretical and legal category "termination" in relation to the said person's mandate as, according to formal logic rules, the above definition includes the terms "expiry" and "premature termination" of a parliamentary mandate. Meanwhile, we believe that the grounds for terminating an MP's powers may be divided into two types.

Thus, in the first case the mandate is terminated pursuant to the expiration of the constitutional term of the said person's authority.

As we have said above, both Polish and Belarusian parliamentary mandates last for four years. The term depends on the respective Parliaments' legislature and is set by the Constitution. Note that the provision that determines the interval between parliamentary elections corresponds to Protocol No.1 to the Council of Europe's Convention for the Protection of Human Rights and Fundamental Freedoms. This demonstrates adherence by the two countries in question to the generally recognized rules of international law. As A.A. Bezuglov rightly says, a deputy's term of office cannot be too short as this does not allow the deputy to acquire the practical skills required "for state management". Besides, too frequent renewal of representative bodies hinders their performance. ${ }^{8}$ We believe that the respective Constitutions set the best possible terms of office for Polish and Belarusian MPs, insofar that the current stage of Polish parliamentary system development as well as when deputies to the House of Representatives perform their parliamentary duties full-time (unless the Constitution of the Republic of Belarus provides otherwise) and members of

$7 \quad$ Nudnenko L.A., Constitutional..., op. cit., p. 149-150.

8 Bezuglov A.A., Sovetsky..., op. cit., p. 20. 
the Council of the Republic perform their duties full-time or outside normal working hours, the legislative body's term of office should be quite lengthy (4-6 years).

In the second case a parliamentary mandate is terminated, as we see it, due to premature termination of the MPs' powers as well as in the case of a premature dissolution of Parliament, which we consider an exception to the above rule.

Note that pursuant to the framework law, ${ }^{9}$ the authority of a deputy to the House of Representatives or a member of the Council of the Republic, is prematurely terminated by the decision of the respective chamber: 1) if the deputy to the House of Representatives or a member of the Council of the Republic is elected or appointed to a post incompatible with performing the duties of a deputy to the House of Representatives or a member of the Council of the Republic pursuant to the Constitution of the Republic of Belarus and the framework law; 2) if the deputy to the House of Representatives or a member of the Council of the Republic files a petition to resign for health reasons or because of other circumstances that prevent them from performing their duty; 3 ) if they are declared fully or partially incapacitated by the court; 4) if a deputy to the newly elected House of Representatives refuses to relinquish their previous employment within three months and commit to working full-time in the House of Representatives; 5) if the elections or the powers of certain deputies to the House of Representatives or members of the Council of the Republic are held invalid; 6) if there is a conviction in force brought by the Supreme Court of the Republic of Belarus concerning a person who is a deputy to the House of Representatives or a Member of the Council of the Republic; 7) if Belarusian citizenship is revoked; 8) if a deputy to the House of Representatives or a member of the Council of the Republic is recalled; 9) if the obligation provided for by Section 9, Article 6, of this framework law has not been signed; 10) if there is a resignation notice has been submitted by a deputy to the House of Representatives or a member of the Council of the Republic for personal reasons.

The last of the grounds listed above for premature termination of MPs' powers, leads us pay special attention to a very fair point made by the Russian researcher A.A. Bezuglov, who discusses the issue of premature termination of MPs' powers to emphasise "...how easy it is for them to do it at will: it's enough to write a resignation notice, ... join the management board of a corporation or another business entity, become an entrepreneur" ${ }^{10}$ This is a topical issue for any state (including Belarus and Poland) - the complicated procedure of acquiring a parliamentary mandate that involves overcoming a number of challenges, both financial and political, is quite common and constitutes an important issue for every state. The state budget

9 About the status of the deputy of the House of Representatives, member of the Council of the Republic of the National Assembly of the Republic of Belarus: Law of the Republic of Belarus, 04.11.1998, No. 196-Z: in an edition. Law of the Republic of Belarus of 17.07.2018. 
The Legal Grounds of Emergence and Termination of Mandates of Members...

funds allocated for the election of a "failing" MP, might have been spent much more efficiently on providing say maternity and child welfare, which would definitely be in line with the social policy of our country. Therefore, we consider it reasonable to oblige Belarusian MPs who wish to prematurely terminate their duties for the above reason, to pay a fixed monetary penalty into the national budget to compensate the expenses incurred by the state in supporting their election campaign. This measure would secure the best possible goal-oriented allocation of funds raised from Belarusian taxpayers, which is crucial for a democratic state of law. Thus, we think it necessary to introduce a corresponding amendment to Article 8 of the existing framework law.

It would also make sense to review the previous ground for premature termination of MPs' powers, when there is a conviction in force against them brought by the Supreme Court of the Republic of Belarus. We believe that to secure the best possible performance of the Belarusian Parliament, premature termination of MPs' powers only becomes sensible when there is a conviction brought against an MP by the above court that entails community service, imprisonment, restriction or deprivation of liberty, life sentence or capital punishment, as well as denial of the right to hold certain positions or perform certain activities (we consider these types of punishment incompatible with efficient parliamentary performance), but not all kinds of conviction.

The framework law states that the authority of full-time members of the Belarusian Parliament may also be terminated by the corresponding parliamentary chamber in cases of failure to submit an income and owned property return or wilful presentation of incomplete or false information; failure to meet the restrictions set in Sections 4-6, Article 6, of said law.

In the case of premature dissolution of the House of Representatives or the Council of the Republic (also in cases where a deputy of the House of Representatives or a member of the Council of the Republic dies) the authority of MPs is terminated without need of a resolution by the corresponding chamber of the National Assembly of the Republic of Belarus. The President of the Republic makes a decision on the premature dissolution of the National Assembly chambers within two months from seeking official advice from the chairs of those chambers.

In view of the above, it is important to emphasize that Belarusian legislation provides for a number of situations that make it impossible to dissolve the chambers of the National Assembly: a state of emergency or martial law; during the last six months of the President's term of office; in the course of proceedings of both chambers of the National Assembly on the premature resignation or removal of the President from office; during the course of the first year since the first sittings were held.

We believe that the current list of grounds for premature termination of Belarusian MPs' authority could be a bit more extensive. In particular, to enhance the performance of MPs the above list may be supplemented with several other grounds, for 
example: an MP leaving the country for permanent residence abroad; voluntary dissolution of the House of Representatives or the Council of the Republic of the National Assembly and some others.

It should be noted that in some foreign countries a political party may initiate premature termination of powers if an MP ceases to belong to the party in which they were elected. ${ }^{11}$ We believe that this statutory regulation is inefficient as it entails substantial restrictions for the MP as a representative of the people. Belarusian legislation does not contain this provision.

The list of premature termination grounds laid down by the Polish legislation does not contain the above case either. This list is less extensive than the Belarusian one and sets the following grounds for premature termination of a Polish National Assembly mandate.

In particular, national legislation provides for premature termination of a Sejm deputy's mandate on grounds of a refusal or failure by the delegate to take the oath. In such event, the Marshal of the Lower Chamber of the Parliament, having consulted the Operating Procedure and Deputy Affairs Commission, decides on approving the premature termination of the failing deputy's mandate, as well as on substitution of the surrendered mandate, formulating this as a resolution to be published in the Official Bulletin of the Polish Republic "Monitor Polski".

It looks like the above list of grounds for premature termination of a Polish National Assembly mandate should be supplemented with one more ground: unreasonable failure of a Sejm deputy or member of the Senate to attend a certain number of sittings of the corresponding chamber of the Polish Parliament. This ground for premature termination of a representative's mandate as a form of certain political responsibility of a given elected politician, as we see it, might serve to render his/her full-time performance more effective.

In light of the above, let us note that this legal rule is in no way the only reason for premature termination of a Polish MP's authority.

The regulatory body of Poland also sets the rule that dissolution of the parliamentary chambers may constitute grounds for premature termination of the Sejm's deputies and members of the Senate. In particular, the Sejm may shorten its term of office by a resolution passed by a majority of at least two-thirds of the votes of the statutory number of deputies. It is important to note that any shortening of the term of office of the Sejm shall simultaneously mean a corresponding shortening of the term of office of the Senate.

Polish legislation provides for one more ground for premature dissolution of the parliamentary chambers' authority and, consequently, the mandates of its members. Thus, the President, after seeking the opinion of the Marshal of the Sejm and the

11 Krylova N.S., The constitutional models of legislature, (in:) N.S. Krylova, Comparative constitutional law, Moscow 2002, p. 327. 
The Legal Grounds of Emergence and Termination of Mandates of Members...

Marshal of the Senate, may, in instances specified in the Constitution, Articles 155 and 225, order the shortening of the Sejm's term of office.

In particular, pursuant to Article 155 of the Constitution, in the event that a Council of Ministers has not been appointed pursuant to the provisions of Article 154, para. 3, the President of the Republic shall, within a period of 14 days, appoint a Prime Minister and, on his application, other members of the Council of Ministers and accept their oaths of office. The Sejm, within 14 days following the appointment of the Council of Ministers by the President of the Republic, holds, in the presence of at least half of the statutory number of deputies, a vote of confidence thereto. In the event that a vote of confidence has not been granted to the Council of Ministers, then pursuant to para. 1, the President of the Republic shortens the term of office of the Sejm and orders elections to be held. Further, pursuant to Article 225 of the Polish Constitution, if, after 4 months from the day of submission of a draft budget to the Sejm, it has not been presented to the President of the Republic for signature, the President may, within the following 14 days, order the shortening of the Sejm's term of office.

As before, whenever the term of office of the Sejm has been shortened by the Polish President, then the term of office of the Senate is also shortened. In addition, having issued such an order, the President is required to simultaneously order elections to the Sejm and the Senate, and order them to be held on a day falling within a period of 45 days from the date on which the official announcement of the Presidential order was issued, and thereafter, to summon the first sitting of the newly elected Sejm by no later than the $15^{\text {th }}$ day after the date on which the elections were held. Note that the full list of the grounds for terminating a Sejm deputy's mandate or that of a member of the Senate is set by Article 213 of the Polish Law of 12 April 2001.

\section{Conclusions}

So, analysing the regulatory origin of the grounds for granting and terminating mandates of the Sejm's deputies and senators set by the legislative bodies of the states in question and comparing them to the similar legal categories applied to the status structures of deputies to the House of Representatives and Members of the Council of the Republic, we can find both similar and different features in these powers. A large number of similar legislative provisions (which prevail) relate to their essence (details) and, as we see it, they are preconditioned mainly by the common origin of the Polish and Belarusian parliamentary institutions. Their main point is that the grounds for granting and terminating parliamentary mandates, as an integral element of their legal status, sets the time frame for exercising the authority of both Polish and Belarusian members of parliament. The existing differences between the 


\section{Aksana Chmyha}

above legal categories manifest themselves, first and foremost, in their formal expression - the implementation procedure.

\section{BIBLIOGRAPHY}

Bezuglov A.A., Constitutional law of Russia, Moscow 2001.

Bezuglov A.A., Sovetsky deputy. State and legal status, Moscow 1971.

Garlicki L., Polskie prawo konstytucyjne, zarys wykładu, Warszawa 2011.

Grajewski K., Status prawny posła i senatora, Warszawa 2006.

Krylova N.S., The constitutional models of legislature, (in:) N.S. Krylova, Comparative constitutional law, M.oscow 2002.

Nudnenko L.A,. Constitutional legal status of the deputy of the legislature governmental body in the Russian Federation, Sankt Petersburg 2004.

Sarnecki P. (ed.), Prawo konstytucyjne Rzeczypospolitej Polskiej, Warszawa 2011.

Skrzydło W. (ed.), Polskie prawo konstytucyjne, Lublin 2008.

Vasilevich G.A., The constitution and problems of improvement of electoral law in the Republic of Belarus, "Journal of russian law" 1999, no. 5/6. 